\title{
THE STUDY OF FIBROBLAST GROWTH FACTOR-2, SULFATED GLYCOSAMINOGLYCANS AND OXYPROLINE WITH MITRAL VALVE PROLAPSE IN COMBINATION WITH TYPE 1 DIABETES MELLITUS
}

\author{
Olena Nikolenko \\ Department of General Practice \\ V. N. Karazin Kharkiv National University \\ 4 Svobody sq., Kharkiv, Ukraine, 61022 \\ olena.nikolenko.kh@gmail.com \\ Oleksii Korzh \\ Department of General Practice \\ Kharkiv Medical Academy of Postgraduate Education \\ 58 Amosova str., Kharkiv, Ukraine, 61176 \\ zpsm@med.edu.ua
}

\begin{abstract}
The aim. The aim of the study was to conduct a comparative analysis of fibroblast growth factor-2, the total content and fractions of sulfated glycosoaminoglycans as well as free and peptide-bounding oxyproline as the markers of connective tissue metabolism in young patients with mitral valve prolapse, type 1 diabetes mellitus and the combination of both indications.

Materials and methods. 93 patients between 19 and 33 years old with either mitral valve prolapse, or type 1 diabetes or the combination of both indications were examined. Group 1 was represented by 36 patients with the monomorbid type 1 diabetes mellitus. Group 2 consisted of 33 patients with type 1 diabetes mellitus and mitral valve prolapse. The comparison group included 24 people with diagnosed mitral valve prolapse. The concentration of fibroblast growth factor-2 in blood plasma was determined by the enzyme immunoassay using a Quantikine reagent kit (Human FGF basic Immunoassay), manufactured by R\&D Systems, Inc. (USA) and expressed in $\mathrm{pg} / \mathrm{ml}$. The total content and fractions of glycosaminoglycans in blood serum were determined by the method of N. G. Stern et al. and expressed in units of optical density. The level of free and peptide-bounding oxyproline in blood serum were determined by the method of P. N. Sharaev and expressed in $\mu \mathrm{mol} / \mathrm{L}$.

Results. Fibroblast growth factor-2 was higher in group 2, where it was $23.7 \pm 0.25 \mathrm{pg} / \mathrm{ml}$ compared to the control group $14.20 \pm 0.22 \mathrm{pg} / \mathrm{ml}(p<0.01)$. There was also a significant difference in the levels of fibroblast growth factor-2 between groups 1 where it equaled $15.33 \pm 0.24 \mathrm{pg} / \mathrm{ml}$ and $2-23.71 \pm 0.25 \mathrm{pg} / \mathrm{ml}(p<0.01)$. The total content of glycosaminoglycans in comparison with the control group, where it was equal to $9.7 \pm 0.62 \mathrm{odu}$, was higher in all groups of patients: in group 1 it was $12.07 \pm 1.04 \mathrm{odu}$, in the comparison group it was $11.75 \pm 0.83$ odu, in the group with the combined pathology it was $13.32 \pm 1.59$ odu $(p<0.05)$. The values of glycosaminoglycans II fraction, were higher in group $2-4.96 \pm 0.59 \mathrm{odu}$. The level of peptide-bound oxyproline, just as the level of free oxyproline, significantly increased in patients with comorbid pathology in group 2, compared to the control group: $16.06 \pm 1.54 \mu \mathrm{mol} / 1$ versus $8.7 \pm 0.81 \mu \mathrm{mol} / 1(p<0.01)$ respectively.

Conclusions. The values of fibroblast growth factor-2, glycosaminoglycans II fraction, free and peptide-bound oxyproline were significantly higher in patients with diabetes mellitus and mitral valve prolapse in comparison with the control group. Fibroblast growth factor-2 was higher in patients with comorbid pathology compared to the monomorbid diabetes patients.

Keywords: mitral valve prolapse, diabetes mellitus, fibroblast growth factor-2, glycosaminoglycans, free and peptide-bound oxyproline.
\end{abstract}

DOI: $10.21303 / 2504-5679.2021 .001653$

\section{Introduction}

Connective tissue is one of the most prevalent and functionally loaded tissue structures in the body. It actively participates in the regulation of metabolic processes, providing the synthesis and secretion of cytokines, growth factors, tissue hormones, enzymes, etc. Furthermore, it has a regulatory effect on reproduction, differentiation of cells, the intercellular substance metabolism and, as a consequence, the formation of organ structures at the embryonic and postnatal development stages. The regenerative properties of fibroblasts provide the plastic function of the 
connective tissue. Connective tissue is represented by a cellular component, fibrillar structures (collagen, elastin), as well as glycoproteins and proteoglycans. Glycosoaminoglycans (GAGs) are the carbohydrate part both of glycoproteins and proteoglycans and form the extracellular matrix [1, 2]. The physicochemical properties of collagen change under pathological influences [3]. Oxyproline is one of the main aminoacids of collagen, which makes free oxyproline and peptide-binding oxyproline one of the most significant biomarkers of collagen metabolism [4].

An increased content of free oxyproline in the blood may indicate collagen hypercatabolism. Peptide-binding oxyproline is a product of incomplete collagen decay. It is indirectly associated with the presence of atypical pathological forms of collagen and the processes of degradation of connective tissue. Accordingly, the ratio of the free and peptide-binded oxyproline to a certain extent reflect, the tendencies of increased synthesis or pathological decomposition of collagen, which can take place simultaneously [5].

The sulfated GAGs, which are the primary markers of connective tissue dysplastic processes, take a special place in the metabolic processes of connective tissue. GAG fractions are specific according to various tissue structures. The GAG fraction I is found mainly in cartilage, tendons and ligaments. The main substance of the connective tissue of the heart valve apparatus is represented by the GAG fraction II. The GAG fraction III is involved in the structure of the basal membranes of blood vessels [6].

Fibroblast growth factors (FGF) take their place in the regulation of metabolic processes of connective tissue, among which fibroblast growth factor-2 (FGF-2) is tropic to heart valve apparatus. Some research is being done on the role of FGF-2 in relation to its direct participation in the formation of pathological disorders of connective tissue of cardiac structures during embryogenesis and in the postnatal period [7]. However, the studies of the FGF-2 role in morphofunctional changes development in valves and myocardium due to dysmetabolic change, in comparison with proteoglycan parameters of connective tissue metabolism combined with mitral valve prolapse are insufficient.

Mitral valve prolapse (MVP) is one of the most common cardiac manifestations of the undifferentiated dysplasia of connective tissue [8,9], which is considered as a separate nosological unit [10]. In case of the predominantly positive clinical picture of mitral valve prolapse, the quality of life and the mental condition are deteriorating upon the complicated course [11]. Should the development of myxomatous degeneration of the heart valve apparatus be associated with it, there is a threat of heart failure as well as syncope $[12,13]$. MVP is the main cause of cardiac surgery for mitral regurgitation and high-grade arrhythmias [14, 15]. Myxomatous degeneration of heart valve apparatus is caused by genetically determined and phenotypic disorders of metabolic processes in connective tissue $[16,17]$. The causes of damage to the spongiosa of mitral valve are an increase in the level of hydration through GAG and fibrillogenesis disorder, indicated by oxyproline metabolism and influenced by FGF-2. These factors lead to the microstructure disorder as well as the functional ability of the mitral valve [7].

In case of diabetes mellitus (DM), dysmetabolic processes of connective tissue and of the carbohydrate metabolism develop simultaneously and are interdependent. Connective tissue dysplasia can be a background for the development and progression of diabetes. In turn, microvascular damages that are inherent in diabetes can deepen degenerative processes in the heart valve apparatus. Thus, the relationship between connective tissue dysplasia, the main cardiac manifestation of which being MVP, and the development of diabetes may be quite expected [18].

The aim: to perform a comparative analysis of FGF-2, the total content and fractions of sulfitized GAGs as well as free and peptide-bounding oxyproline as the markers of connective tissue metabolism in young patients with mitral valve prolapse, type 1 diabetes mellitus and the combination of both indications.

\section{Materials and methods}

93 patients between 19 and 33 years old with either MVP, or type 1 diabetes mellitus (DM1) or the combination of both indications were examined (average age of the examined patients was $26.3+0.94)$. Overall 69 patients suffered from diabetes. Group 1 was represented by 36 patients 
with the monomorbid DM1. Group 2 consisted of 33 patients with DM1 and MVP. The comparison group included 24 people with diagnosed MVP. In group 1 the average age was $27.43 \pm 1.17$ years, in group 2 it laid by $26.88 \pm 1.05$ years, in comparison group it was $23.9+1.3$ years. The control group included 22 virtually healthy individuals. The patients were in inpatient treatment in the endocrinology department of the CNC KhRC «Regional Clinical Hospital». The research was conducted during 2017-2020.

During the study the principles of the Declaration of Helsinki adopted by the General Assembly of the World Medical Association (1964-2000), the Council of Europe Convention on Human Rights and Biomedicine (1997), the relevant provisions of the WHO, the International Council of Medical Scientific Communities, the International Code of Medical ethics (1983) and the laws of Ukraine were followed. It was approved by ethics committee at Kharkiv Medical Academy of Postgraduate Education (protocol No. 8 of 27.09.2017). All patients voluntarily signed an informed consent before starting the study.

The diagnosis of type 1 diabetes was established according to the order of the Ministry of Health of Ukraine No. 1021 from 27th of June, 2014 [19]. The diagnosis of MVP and the main indicators of EchoCG were established according to the echocardiographic criteria of L. Freed et al. (2002) and Bonow R. O. et al., (2006) [20, 21].

The concentration of FGF-2 in blood plasma was determined by the enzyme immunoassay using a Quantikine reagent kit (Human FGF basic Immunoassay), manufactured by R\&D Systems, Inc. (USA) and expressed in pg/ml. The total content and fractions of GAGs in blood serum were determined by the method of N. G. Stern et al. [22] and expressed in units of optical density. The level of free and peptide-bounding oxyproline in blood serum were determined by the method of P. N. Sharaev [23] and expressed in $\mu \mathrm{mol} / \mathrm{L}$. Furthermore, the ratio of free and peptide-bounding oxyproline was calculated.

Statistical data processing was implemented using the methods of variation statistics and the Statistica 6.0 software package. Unpaired Student's t-test was used when comparing the results, depending on the normality of the distribution, to identify significant differences. The significance level for testing statistical hypotheses when comparing groups was $<0.05$.

\section{Results}

There is a change in the physicochemical properties of collagen and proteoglycans in dysplastic processes of connective tissue, leading to activation and proliferation of the connective tissue cellular component and, furthermore, to the activation of proteolytic enzymes as well as to the deformation of the structural collagen fibers [5, 15].

The content of free oxyproline, which is the marker of collagen synthesis and degradation, significantly increased in patients of group 2 with a combination of type 1 diabetes mellitus and mitral valve prolapse, compared to the control group, $(p<0.05)$ (Table 1). When comparing groups of patients with each other, no significant differences were found in terms of free oxyproline. The value reflects the process of collagen degradation. An increase in the content of free oxyproline in patients with concomitant pathology may indicate an increase in the intensity of destructive processes in the collagen metabolism, which corresponds to the presence of a subclinical chronic inflammatory process of low intensity and is a pathological part of the development of diabetes vascular complications (Table 1).

The peptide-bound oxyproline was more informative as a marker of pathological synthesis and incomplete collagen decomposition. The level of peptide-bound oxyproline, just as the level of free oxyproline, significantly increased in patients with comorbid pathology in group 2 , compared to the control group: $16.06 \pm 1.54 \mu \mathrm{mol} / 1$ versus $8.7 \pm 0.81 \mu \mathrm{mol} / 1(p<0.01)$ respectively. Also, a significant increase in measured values of peptide-bound oxyproline in this group could be determined in comparison with group 1 where it was $12.38 \pm 1.34 \mu \mathrm{mol} \backslash \mathrm{L}$ and the comparison group $-10.18 \pm 1.85 \mu$ mol $\backslash \mathrm{L}(p<0.05)$.

The ratio of free oxyproline and peptide-bound oxyproline levels, which reflects the balance of collagen synthesis and degradation, was [25.9\%] lower in patients of group 2 than in the comparison group and significantly lower than in the control group by [35.7\%] due to the relative 
increase in the proportion of peptide-bound oxyproline. The data obtained indicate a relative imbalance of the connective tissue anabolism and catabolism in case of a combination of diabetes and MVP. Furthermore, it is an indication for the increased pathological changes in the connective tissue metabolism, which can lead to remodelling and myxomatous degeneration of its structure.

Table 1

Levels of free oxyproline and peptide-bound oxyproline in the blood serum of patients with MVP, DM1 and the combination of both

\begin{tabular}{|c|c|c|c|c|c|}
\hline Indicators & $\begin{array}{c}\text { Group 1 } \\
\text { (monomorbid DM1) }\end{array}$ & $\begin{array}{c}\text { Group } 2 \\
\text { (DM1+MVP) }\end{array}$ & $\begin{array}{l}\text { Comparison group1 } \\
\text { (monomorbid MVP) }\end{array}$ & $\begin{array}{l}\text { Control } \\
\text { group }\end{array}$ & $p$-value \\
\hline free oxyproline, $\mu \mathrm{mol} / 1$ & $15.10 \pm 1.21$ & $17.98 \pm 2.02$ & $14.37 \pm 2.69$ & $13.20 \pm 1.16$ & $\begin{aligned} p 1-2 & =0.226 \\
p 1-3 & =0.805 \\
p 1-4 & =0.262 \\
p 2-3 & =0.288 \\
p 2-4 & <0.05 \\
p 3-4 & =0.691\end{aligned}$ \\
\hline $\begin{array}{l}\text { peptide-bound oxypro- } \\
\text { line, } \mu \mathrm{mol} / 1\end{array}$ & $12.38 \pm 1.34$ & $16.06 \pm 1.54$ & $10.18 \pm 1.85$ & $8.70 \pm 0.81$ & $\begin{aligned} p 1-2 & =0.077 \\
p 1-3 & =0.339 \\
p 1-4 & <0.05 \\
p 2-3 & <0.05 \\
p 2-4 & <0.001 \\
p 3-4 & =0.465\end{aligned}$ \\
\hline
\end{tabular}

The ratio of free oxypro1.22 1.12 1.41 1.52 line and peptide-bound oxyproline

Note: the index $r$ of the p-value corresponds to the reference value. The indices 1, 2 and 3 correspond to the numbers of the comparison groups

GAG changes are primary relative to the onset of collagen degradation processes. They advance fibrillogenesis, since the disruption of biopolymer synthesis is secondary to the proteoglycans metabolism, which are significantly influenced by growth factors, namely FGF-2.

The total content of GAG in comparison with the control group, where it was equal to [9.7 \pm 0.62$]$ odu, was higher in all groups of patients: in group 1 it was [12.07 \pm 1.04$]$ odu, in the comparison group it was [11.75 \pm 0.83$]$ odu. In the group with the combined pathology it was even higher [13.32 \pm 1.59$]$ odu, $(p<0.05)$. The values of GAG II fraction, which is represented in the main substance of the heart valve apparatus, were higher in group 2 and the comparison group [4.96 \pm 0.59$]$ odu and [4.35 \pm 1.83$]$ odu respectively, compared to the control group $[3.14 \pm 0.2]$ odu $(p<0.05)$. The values of GAG III fraction were higher in diabetes patients in group 1 and 2 . This is reliably due to the presence of heparan sulfate in the lamina densa of the basal membranes of blood vessels, which is a part of the GAG III fraction, and may indicate microangiopathic complications (Table 2).

Fibroblast growth factor-2 was higher in group 2, where it was $23.7 \pm 0.25 \mathrm{pg} / \mathrm{ml}$ and in the comparison group, where it was equal to $18.11 \pm 0.21 \mathrm{pg} / \mathrm{ml}$, compared to the control group $-14.20 \pm 0.22 \mathrm{pg} / \mathrm{ml}(p<0.01)$. There was also a significant difference in the levels of FGF-2 between groups 1 and 2 in diabetes patients. It was equal to $15.33 \pm 0.24 \mathrm{pg} / \mathrm{ml}$ and reached $23.71 \pm 0.25 \mathrm{pg} / \mathrm{ml}$ respectively, probably due to the presence of MVP in the group with comorbid pathology $(p<0.01)$.

In patients with a diabetes duration over 10 years from the moment of clinical manifestation $(n=30)$, the value of FGF-2 was $19.71 \pm 0.25 \mathrm{pg} / \mathrm{ml}$, significantly exceeding this indicator in 32 patients with a diabetes duration under 10 years $-18.89 \pm 0.21 \mathrm{pg} / \mathrm{ml}, p<0.05$. A high level of FGF-2 was observed in the subgroup of patients with comorbid pathology with diabetes duration over 10 years: $24.22 \pm 0.49 \mathrm{pg} / \mathrm{ml}$ versus $14.20 \pm 0.22 \mathrm{pg} / \mathrm{ml}$ in the control group $(p<0.01)$. 
Table 2

The content of GAGs and its fractions in the blood serum of patients with type 1 diabetes, MVP and its combination

\begin{tabular}{|c|c|c|c|c|c|}
\hline Indicators & $\begin{array}{c}\text { Group 1 } \\
\text { (monomorbid DM1) }\end{array}$ & $\begin{array}{c}\text { Group 2 } \\
(\mathrm{DM} 1+\mathrm{MVP})\end{array}$ & $\begin{array}{l}\text { Comparison group1 } \\
\text { (monomorbid MVP) }\end{array}$ & $\begin{array}{l}\text { Control } \\
\text { group }\end{array}$ & $p$-value \\
\hline GAGs, total content, odu & $12.07 \pm 1.04$ & $13.32 \pm 1.59$ & $11.75 \pm 0.83$ & $9.7 \pm 0.62$ & $\begin{array}{c}p 1-2=0.503 \\
p 1-3=0.828 \\
p 1-4=0.058 \\
p 2-3=0.385 \\
p 2-4<0.05 \\
p 3-4=0.0053\end{array}$ \\
\hline GAG,I fraction, odu & $6.46 \pm 3.28$ & $7.06 \pm 2.34$ & $5.94 \pm 1.47$ & $5.19 \pm 1.08$ & $\begin{array}{l}p 1-2=0.882 \\
p 1-3=0.885 \\
p 1-4=0.714 \\
p 2-3=0.743 \\
p 2-4=0.471 \\
p 3-4=0.683\end{array}$ \\
\hline GAG,II fraction, odu & $4.35 \pm 1.83$ & $4.96 \pm 0.59$ & $4.7 \pm 0.60$ & $3.14 \pm 0.20$ & $\begin{array}{l}p 1-2=0.752 \\
p 1-3=0.856 \\
p 1-4=0.514 \\
p 2-3=0.759 \\
p 2-4<0.001 \\
p 3-4<0.002\end{array}$ \\
\hline GAG,III fraction, odu & $2.5 \pm 0.80$ & $4.2 \pm 0.60$ & $3.9 \pm 0.50$ & $2.61 \pm 0.40$ & $\begin{array}{c}p 1-2<0.02 \\
p 1-3<0.02 \\
p 1-4=0.827 \\
p 2-3=0.702 \\
p 2-4<0.05 \\
p 3-4<0.05\end{array}$ \\
\hline
\end{tabular}

Note: the index $r$ of the p-value corresponds to the reference value. The indices 1, 2 and 3 correspond to the numbers of the comparison groups

\section{Discussion}

The level of free oxyproline reflects the processes of collagen degradation [6], while peptide-bound oxyproline additionally represents the intensity of pathological collagen synthesis. Autoregulation of connective tissue metabolism is based on a correlation between the synthesis and catabolism of collagen. A simultaneous increase in the level of free oxyproline and peptide-bound oxyproline, which was higher in diabetes patients, may indicate a violation of this autoregulatory mechanism. As a result of increasing in the intensity of destructive processes in the connective tissue can be the activation of inflammation. It is known that even low intensity of chronic inflammation is one of the important mechanisms in the diabetes mellitus development and its vascular complications. Changes in physicochemical properties concern not only collagen, but also GAGs (carbohydrate components of proteoglycans), which were higher among patients with MVP.

The obtained data indicated the informative value of significant differences between the groups of patients and the control group relative to the GAG II fraction, both in combined pathology and in monomorbid MVP, as well as to the GAG III fraction in diabetes, when compared with the comparison group. FGF-2 indices were significantly higher in the group with comorbid pathology, probably due to the presence of MVP $(p<0.01)$. Also, FGF-2 was significantly higher in case of the diabetes duration of more than 10 years from the moment of clinical manifestation $(p<0.05)$.

Study limitations. Relatively long time for the examination of patients with comorbid pathology in comparison with monomorbid groups of patients. 
Prospects for further research. The research will be further continued by a study of collagen metabolism indicators, FGF-2, GAGs, free and peptide-bound oxyproline and its comparison with indicators of intracardiac kinetics of the left ventricle.

\section{Conclusions}

1. The content of free and peptide-bound oxyproline in the blood serum of the examined patients compared with the control group was significantly higher in patients with type 1 diabetes combined with MVP $(p<0.05)$.

2. A significant increase of peptide-bound oxyproline in group 2 in comparison to group 1 and the comparison group was identified: $12.38 \pm 1.34 \mu \mathrm{mol} \backslash \mathrm{L}$ and $10.18 \pm 1.85 \mu \mathrm{mol} \backslash \mathrm{L}$ respectively $(p<0.05)$.

3. Levels of GAG II fraction were significantly higher in groups with MVP: $4.96 \pm 0.59$ (group 2) and $4.35 \pm 1.83$ (comparison group), compared with the control group where it reached $3.14 \pm 0.2(p<0.05)$.

4. GAG III fraction was prevailing in diabetic patients, regardless of the presence or absence of MVP, and was reliably associated with the development of diabetic microangiopathies.

5. FGF-2 in patients of group 2 were significantly higher compared to the control group, group 1 and the comparison group. They were also significantly lower in group 1 compared to the comparison group.

\section{Conflicts of interest}

The authors declare that they have no conflicts of interest.

\section{References}

[1] Pavlov, S. B., Pavlova, G. B. (2016). Study the role of intercellular mediators in the metabolism of connective tissue in children with cardiomyopathy and osteopeny. Journal of Education, Healthand Sport, 6 (9), 902-916. doi: http://dx.doi.org/10.5281/ zenodo. 163528

[2] Martynov, A., Nechaeva, G. (2018). Guidelines of the Russian scientific medical society of internal medicine on the diagnosis, treatment and rehabilitation of patients with the connective tissue dysplasia (first edition). Medical News of the North Caucasus, 13 (1-2), 137-209. doi: http://doi.org/10.14300/mnnc.2018.13037

[3] Khvysyuk, O. N., Pavlov, S. B., Pavlova, G. B. (2016). On the question of the role of the functional state of connective tissue in the implementation of the systemic response to damage. Problems of continuous medical education and science, 3, 55-61.

[4] Pavlov, S. B., Zukow, W. (2016). Violation of collagen metabolism in the development of renal scarring in patients with chronic pyelonephritis. Journal of Education, Health and Sport, 6 (6), 263-278. doi: http://dx.doi.org/10.5281/zenodo.55365

[5] Zakhvatov, A. N., Tarasova, T. V., Avanesov, A. M., Zakharkin, I. A., Khaidar, D. A., Chekmaeva, A. A., Sermina, T. A. (2018). Korrektsiia narushenii obmena kollagena pri artrite posttravmaticheskogo geneza. Puls, 20 (12), 193-197.

[6] Arsentev, V. G., Sereda, Iu. V., Tikhonov, V. V. (2011). Displazii soedinitelnoi tkani - konstitutsionalnaia osnova poliorgannykh narushenii u detei i podrostkov. Pediatriia. Zhurnal im. G. N. Speranskogo, 90 (5), 54-57.

[7] Zimering, M. B., Anderson, R. J., Ge, L., Moritz, T. E., Duckworth, W. C. (2013). Basic fibroblast growth factor predicts cardiovascular disease occurrence in participants from the veterans affairs diabetes trial. Front Endocrinol, 4. doi: http:// doi.org/10.3389/fendo.2013.00183

[8] Althunayyan, A., Petersen, S. E., Lloyd, G., Bhattacharyya, S. (2018). Mitral valve prolapse. Expert Review of Cardiovascular Therapy, 17 (1), 43-51. doi: http://doi.org/10.1080/14779072.2019.1553619

[9] Mecarocci V., Mori F. (2016). Long-term outcome of primary mitral valve prolapse: results from a population of 250 patients referred to a tertiary cardiovascular center. European Heart Journal - Cardiovascular Imaging, 17 (2), 29-37. doi: http:// doi.org/10.1093/ehjci/jew236.001

[10] International classification of diseases 10th revision (ICD-10). Available at: https://icd.who.int/browse10/2019/en

[11] Bayer-Topilsky, T., Suri, R. M., Topilsky, Y., Marmor, Y. N., Trenerry, M. R., Antiel, R. M. et. al. (2016). Mitral Valve Prolapse, Psychoemotional Status, and Quality of Life: Prospective Investigation in the Current Era. The American Journal of Medicine, 129 (10), 1100-1109. doi: http://doi.org/10.1016/j.amjmed.2016.05.004

[12] Bui, A. H., Roujol, S., Foppa, M., Kissinger, K. V., Goddu, B., Hauser, T. H. et. al. (2016). Diffuse myocardial fibrosis in patients with mitral valve prolapse and ventricular arrhythmia. Heart, 103 (3), 204-209. doi: http://doi.org/10.1136/ heartjnl-2016-309303 
[13] Nalliah, C. J., Mahajan, R., Elliott, A. D., Haqqani, H., Lau, D. H., Vohra, J. K. et. al. (2018). Mitral valve prolapse and sudden cardiac death: a systematic review and meta-analysis. Heart, 105 (2), 144-151. doi: http://doi.org/10.1136/heartjnl-2017-312932

[14] Perazzolo Marra, M., Basso, C., De Lazzari, M., Rizzo, S., Cipriani, A., Giorgi, B. et. al. (2016). Morphofunctional Abnormalities of Mitral Annulus and Arrhythmic Mitral Valve Prolapse. Circulation: Cardiovascular Imaging, 9 (8). doi: http:// doi.org/10.1161/circimaging.116.005030

[15] Rubanenko, A. O., Diachkov, V. A., Shchukin, Yu. V., Rubanenko, O. A., Yurchenko, I. N. (2019). Acquired valvular heart diseases: clinical picture and diagnostics. Cardiology: News, Opinions, Training, 7 (3), 26-36. doi: http://doi.org/10.24411/ 2309-1908-2019-13003

[16] Clavel, M.-A., Mantovani, F., Malouf, J., Michelena, H. I., Vatury, O., Jain, M. S. et. al. (2015). Dynamic Phenotypes of Degenerative Myxomatous Mitral Valve Disease. Circulation: Cardiovascular Imaging, 8 (5). doi: http://doi.org/10.1161/ circimaging.114.002989

[17] Kitkungvan, D., Nabi, F., Kim, R. J., Bonow, R. O., Khan, M. A., Xu, J. et. al. (2018). Myocardial Fibrosis in Patients With Primary Mitral Regurgitation With and Without Prolapse. Journal of the American College of Cardiology, 72 (8), $823-834$. doi: http://doi.org/10.1016/j.jacc.2018.06.048

[18] Alimova, I., Pashinskaya, N., Pleskachevskaja, T. (2016). Peculiarities of diabetes mellitus type 1 in children and adolescents against the background of connective tissue dysplasia. Medical News of the North Caucasus, 11 (2), 272-275. doi: http:// doi.org/10.14300/mnnc.2016.11053

[19] Pro zatverdzhennia ta vprovadzhennia medyko-tekhnolohichnykh dokumentiv zi standartyzatsii medychnoi dopomohy pry tsukrovomu diabeti 1 typu u molodykh liudei ta doroslykh (2014). Nakaz MOZ Ukrainy No. 1021. 29.12.2014. Available at: https://ips.ligazakon.net/document/view/moz24121?an=7\&ed=2014_12_29 Last accessed: 30.04.2020

[20] Freed, L. A., Benjamin, E. J., Levy, D., Larson, M. G., Evans, J. C., Fuller, D. L. et. al. (2002). Mitral valve prolapse in the general population. The benign nature of echocardiography features in the Framingham Heart Study. Journal of the American College of Cardiology, 40 (7), 1298-1304. doi: http://doi.org/10.1016/s0735-1097(02)02161-7

[21] Bonow, R. O., Carabello, B. A., Kanu, C. et. al. (2006). The mitral valve (MV) is situated within a fibrous annulus. Circulation, 114 (5), e84-231.

[22] Shtern, M. R., Timoshenko, O. P., Leonteva, F. S., Kliueva, G. F. (1982). Pat. No. 960626 SU. MPK: G01N 33/48 (2006.01). Sposob opredeleniia glikozaminoglikanov v syvorotke krovi. No. 2998857. declareted: 23.10.1980; published: 23.09.1982.

[23] Sharaev, P. N. (1990). Metod opredeleniia svobodnogo i sviazannogo oksiprolina v syvorotke krovi. Laboratornoe delo, 5, 283-285.

How to cite: Nikolenko, O., Korzh, O. (2021). The study of fibroblast growth factor-2, sulfated glycosaminoglycans and oxyproline with mitral valve prolapse in combination with type 1 diabetes mellitus. EUREKA: Health Sciences, 2, 9-15. doi: http://doi.org/ $10.21303 / 2504-5679.2021 .001653$ 